\title{
Growth and nutritional condition of anchovy larvae on the west and southeast coasts of South Africa
}

\author{
David Costalago $^{1, *}$, Yanasivan Kisten ${ }^{2}$, Catriona Clemmesen ${ }^{3}$, Nadine A. Strydom ${ }^{2}$ \\ ${ }^{1}$ Institute for the Oceans and Fisheries, University of British Columbia. 2202 Main Mall, Vancouver, BC V6T 1Z4, Canada \\ ${ }^{2}$ Department of Zoology, Nelson Mandela University, Port Elizabeth 6031, South Africa \\ ${ }^{3}$ GEOMAR Helmholtz Centre for Ocean Research, Düsternbrooker Weg 20, 24105 Kiel, Germany
}

\begin{abstract}
Cape anchovy Engraulis encrasicolus is an ecologically and economically important pelagic fish species occurring along the coast of South Africa. A recent eastward shift in Cape anchovy distribution indicates that environmental conditions are becoming more favorable for the species on the east coast. This shift is particularly important in the sheltered Algoa Bay region, a nursery area for fish larvae. However, the relatively low productivity of the Agulhas Current Large Marine Ecosystem on the eastern coast of South Africa may result in an anchovy population in poorer nutritional condition and with slower growth rates than the west coast population. Using otolith and nucleic acid analyses, the growth rates of anchovy larvae from the western and southeastern coasts of South Africa were compared. The otolith analysis results indicated that, at any given age, individual growth rates for anchovy larvae were higher on the southeast coast than on the west coast. The RNA:DNA values also indicated that instantaneous growth rates of anchovy larvae were higher in Algoa Bay than on the west coast. At the time of sampling, chlorophyll and zooplankton productivity were higher at sampling sites in Algoa Bay than sites on the west coast, potentially due to favorable oceanographic features in the bay. As such, the results suggest that Algoa Bay is a suitable and potentially favorable nursery area for the early stages of anchovy, highlighting the importance of separate management of the southeast coast region in a changing world.
\end{abstract}

KEY WORDS: Agulhas $\cdot$ Benguela $\cdot$ Cape anchovy $\cdot$ Nursery area $\cdot$ Otoliths $\cdot$ RNA:DNA

\section{INTRODUCTION}

Small pelagic fish species are essential in marine ecosystems because of their relatively high biomass and their trophic role in oceanic food chains (Cury et al. 2000). Fluctuations in these fish populations seem to be primarily caused by environmental variability, thus permeating up to the higher trophic levels and influencing the whole ecosystem through bottom-up forcing (Checkley et al. 2009). Therefore, knowledge of the growth and survival of different life history stages of these species is needed to understand trophic dynamics in pelagic ecosystems. The 2 most commercially and ecologically important small pelagic fish species in South Africa are Cape anchovy
Engraulis encrasicolus (also known as European anchovy) and southern African sardine Sardinops sagax (also known as pilchard) (Fairweather et al. 2006, Van der Lingen et al. 2006). Anchovies and sardines represent South Africa's second largest fishery next to demersal hake, providing $\sim 375000$ tons of catch per annum, predominantly on the west coast (Fairweather et al. 2006, Van der Lingen et al. 2006, Coetzee et al. 2019). Anchovies and sardines caught in purse-seines are usually juveniles, which are either canned or frozen for consumption or processed for fishmeal and oil (Fairweather et al. 2006). Ecologically, these 2 species are among the most important prey for several marine bird species, such as Cape gannets Morus capensis, Cape cormorants Phalacro- 
cocax capensis and African penguins Spheniscus demersus; for marine mammals like Cape fur seals Arctocephalus pusillus, common dolphins Delphinus capensis and common Bryde's whales Balaenoptera brydei; and for many predatory fish species in the region (Crawford et al. 1992, Van der Lingen et al. 2006, Pichegru et al. 2009). Consequently, these pelagic fish species provide a vital trophic link from planktonic primary producers and zooplankton species to these top predators (Cury et al. 2000).

Historically, the bulk of reproduction and recruitment of Cape anchovy and South African sardine in southern Africa occurred off the Atlantic coast, in the Benguela Current system (Hutchings et al. 1998, 2002, Twatwa et al. 2005). This large marine ecosystem (LME) is mainly characterized by the upwelling of colder nutrient-rich waters which supports high productivity and a high biomass of planktonic species, favorable conditions for anchovy (Van der Lingen et al. 2006, Pichegru et al. 2009). In the mid1990s, however, an eastward shift in the recruitment patterns of Cape anchovy was detected, along with higher adult biomasses (Roy et al. 2007). Moreover, some authors have suggested that there are separate sardine and anchovy populations from the west coast off the south and southeast coasts of South Africa and these multiple stocks are now even being considered in management (Fairweather et al. 2006, de Moor \& Butterworth 2015, de Moor et al. 2017). On the southeast coast, high anchovy larvae density has been found in Algoa Bay waters in recent years, highlighting the importance of this area as a nursery (Pattrick \& Strydom 2014, Costalago et al. 2018). This shift in distribution could be due to changes in environmental variables in the south and southeast coasts, driven by climate change (Lamont et al. 2018, Augustyn et al. 2018), and the occurrence of more suitable conditions, such as a decline in water temperature and increase in upwelling occurrences, in this region of the Agulhas (Roy et al. 2007, Costalago et al. 2018). While the effect of environmental variables on the ecology of both sardine and anchovy has been studied extensively in the Benguela Current system (Van der Lingen et al. 2006), less is known about the larval component of their life cycle in the Agulhas Current system. Specifically, Algoa Bay, in the southern range of the influence of the Agulhas Current system, is a region where both larval anchovy and sardine can be found completing the planktonic phase of their life cycles (Pattrick \& Strydom 2008, Costalago et al. 2018).

For engraulid species such as E. encrasicolus, the adults spawn upstream of upwelling areas (i.e. along the Aghulas bank) and the eggs and larvae are trans- ported passively to suitable habitats for feeding, growth and metamorphosis. The juveniles recruit into the fisheries in regions with lower temperatures and higher productivity, such as the Benguela LME north of Cape Columbine, compared to the competitively warmer oligotrophic Aghulas LME on the east coast (Hutchings et al. 1998, 2002, Kirkman et al. 2016, Coetzee et al. 2019). This is similar to Peruvian anchovy E. ringens in the Humboldt Current LME (Hernandez et al. 2014). The recruitment of anchovy into viable populations is often dependent on the growth rate and condition of the individual larvae (García et al. 2003, Takasuka et al. 2007). For example, García et al. (2003) showed that for E. encrasicolus, higher recruitment into the Bay of Málaga coincided with higher growth rates. Meanwhile, Takasuka et al. (2007) indicated that E. japonicus larvae with lower growth rates were more susceptible to predation and thus larvae with higher growth rates showed higher recruitment success. As such, the assessment of the growth and nutritional condition of larvae is integral to understanding recruitment dynamics in these fish populations. Also, while the life histories of Cape anchovy have been studied extensively in the Benguela current LME on the west coast of South Africa, this is not the case for the south and southeast coast.

During the larval phase of the life cycle, otolith microstructures reflect daily growth patterns in fish and can be used to determine the age and daily somatic growth rate of early life history fish (Brothers et al. 1976). For example, a larva that is growing relatively faster would show wider daily increments in its otoliths than a larva with slower growth (Molony \& Choat 1990). Complementarily, the nutritional condition of pelagic fish larvae can be assessed through the estimation of the fish's nucleic acid ratios (RNA:DNA). The amount of DNA in an organism is correlated with the number of cells and is considered constant in somatic tissues. In contrast, the amount of RNA is directly related to the cell's protein synthesis and hence highly dependent on the quantity of food (Catalán et al. 2007). Thus, the RNA:DNA ratio is an index of the organism's protein-synthetic capacity and has been proven to be a useful indicator of nutritional condition (Ferron \& Leggett 1994, Catalán et al. 2007). In several fish species, RNA:DNAderived nutritional condition has been shown to be related to food density and somatic growth (Buckley 1984, Clemmesen 1994, Costalago et al. 2015). For example, the growth and condition of eastern Mediterranean E. encrasicolus was higher during seasonal periods of high temperature and productivity (Schis- 
menou et al. 2013). Even more recently, Do Souto et al. (2019) found seasonal patterns in the growth and condition of E. anchoita. Even factors such as regional climate and relatively sheltered waters may play integral roles in determining nutritional condition of engraulids in different regions (Bergeron 2000, Takahashi \& Watanabe 2005).

It is not known whether potential nursery areas in the lower-productivity oceanographic conditions of waters off the south and east coast of South Africa can support the growth and survival of pelagic fish larvae as well as the nutrient-rich waters off the west coast. A major hypothesis regarding the effects of environmental forcing on the survival and condition of fish larvae is Bakun's 'Ocean Triad' hypothesis (Bakun 1996, Teodósio et al. 2017). This hypothesis consists of 3 factors relevant to the condition of fish: (1) nutrient enrichment due to upwelling or freshwater discharge, (2) concentration of food due to stability and convergence and (3) drift toward or retention of larvae in suitable habitats. The west coast of South Africa, including the Benguela Current system, provides these conditions for anchovy with seasonal nutrient-rich upwelling, as well as transport to and retention of food and pre-recruits in nursery areas north of Cape Columbine (Hutchings et al. 1998, 2002, 2009, Kirkman et al. 2016). Alternatively, Algoa Bay also provides all 3 of these oceanographic conditions. River discharge from the Sundays and

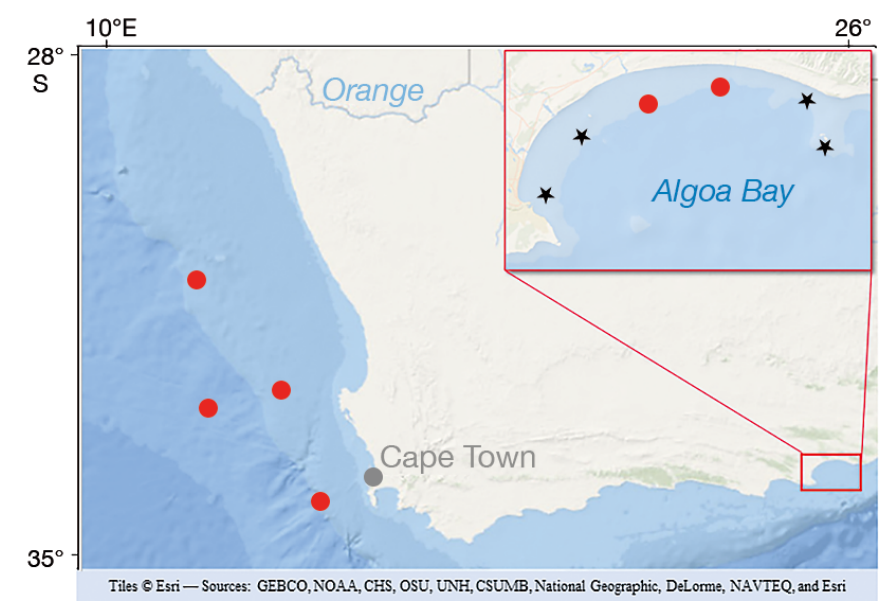

Fig. 1. Map indicating the sampling stations (red points) for oceanographic variables (i.e. temperature, salinity, $\mathrm{O}_{2}$ concentration and chl a concentration from surface to $30 \mathrm{~m}$ ), Cape anchovy larvae and zooplankton off the west coast of South Africa and in Algoa Bay (inset). Black stars indicate the stations in Algoa Bay where only measures of oceanographic variables and zooplankton, but no fish larvae, were collected. Mapping sources: GEBCO, NOAA, CHS, OSU, UNH, CSUMB, National Geographic, DeLorme, NAVTEQ, and $\odot$ Esri
Swartkops estuaries provides nutrients, and strong summer easterly winds create upwelling events (Schumann et al. 1991, Pattrick \& Strydom 2008, Costalago et al. 2018). Winds also move water from the Agulhas Current into Algoa Bay where fish larvae may be retained due to local oceanographic features (Pattrick \& Strydom 2014). As such, the waters of Algoa Bay may provide an ideal nursery area for Cape anchovy (Pattrick \& Strydom 2014). However, the west coast offers a significantly larger area with significantly higher productivity (Hutchings et al. 1998, 2002, 2009). In order to determine the quality of the anchovy nursery area provided by Algoa Bay on the southeast coast, the present study tested the hypothesis that Cape anchovy larvae in Algoa Bay are in poorer nutritional condition and have slower growth rates than larvae in the productive west coast upwelling system.

\section{MATERIALS AND METHODS}

\subsection{Specimen and environmental sampling}

Anchovy larvae were collected from 4 sampling sites in nursery areas off the west coast of South Africa in February 2014, during the second pilot cruise of the Integrated Ecosystem Programme: Southern Benguela (IEP:SB) on the RV 'Algoa' (Fig. 1). Temperature, oxygen concentration, salinity and chlorophyll $a$ values in the top $30 \mathrm{~m}$, and the zooplankton biomass in the entire column, were measured at the 4 sampling stations and averaged for the sampling area. Oceanographic data (temperature, oxygen concentration, salinity, chlorophyll) were taken using a CTD Sea Bird SBE 11 plus. A pair of bongo nets (diameter $750 \mathrm{~mm}$ and $500 \mu \mathrm{m}$ mesh size) and Hydro-Bios MultiNets (200 $\mu \mathrm{m}$ mesh size) were towed from $500 \mathrm{~m}$ to the surface to collect zooplankton and fish larvae. Stepped oblique tows were done at a speed of $\sim 2$ knots with all net types. Zooplankton samples were stored in formalin and the zooplankton biomass as dry weight (as $\mathrm{mg} \mathrm{DW} \mathrm{m}^{-3}$ ) calculated in the laboratory. Anchovy larvae were stored in RNAlater ${ }^{\circledR}$ for nucleic acids analysis $(n=49)$ and in ethanol $(70 \%)$ for otolith analyses $(n=52)$.

Similarly, oceanographic data and anchovy larvae were collected in the Algoa Bay nursery in early March 2014 (Fig. 1). Oceanographic data (taken with a CTD Sea Bird SBE 19 plus) and zooplankton

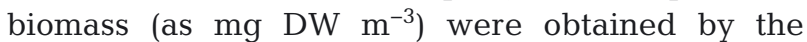
South African Environmental Observation Network (SAEON) during an Algoa Bay Long Term Monitor- 
ing and Research Programme (LTER) cruise on the RV 'uKwabelana'. Temperature, oxygen concentration, salinity and chlorophyll a values in the top $30 \mathrm{~m}$, and the zooplankton biomass in the entire column, were measured at 6 sampling stations and averaged for the sampling area. Anchovy larvae and zooplankton were collected with a ring net (diameter $750 \mathrm{~mm}$ and mesh size $500 \mu \mathrm{m}$ ) on the same day as the oceanographic data. Stepped oblique tows were made at a speed of $\sim 2$ knots. Zooplankton samples were collected from all 6 Algoa Bay stations, but anchovy larvae were only found at 2 of the stations (Fig. 1). Larvae were collected and stored in RNAlater ${ }^{\circledR}$ for nucleic acid analysis and in ethanol (70\%) for otolith analyses. A total of 83 larvae from Algoa Bay were used (total length [TL] range $4.17-25.53 \mathrm{~mm}$, average $10.70 \pm$ $5.44 \mathrm{~mm}), 40$ of them for otolith analyses and 43 of them for nucleic acid analysis. A total of 101 larvae from the west coast were used in this study (TL range $5.12-22.76 \mathrm{~mm}$, average $9.62 \pm 3.32 \mathrm{~mm}$ ), 52 for otolith analyses and 49 for nucleic acid analysis.

\subsection{Otolith extraction and analysis}

Extraction of otoliths was carried out at GEOMAR, Kiel (Germany). Larvae were photographed with a digital camera attached to a Leica MZ95 microscope, and TL of each larva was measured to the nearest $0.01 \mathrm{~mm}$ with ImagePro ${ }^{\circledR}$ Insight software. Using the polarized filter in a binocular microscope, otoliths were located and extracted with fine needles. Only the sagittae were extracted in this study because the microstructures of the lapilli were not as clear as those of the sagittae. The otoliths were individually mounted on microscope glass slides with epoxy resin and photographed using a light microscope at 1001000× magnification (oil immersion was required at the highest magnification) coupled to a digital camera and ImagePro ${ }^{\circledR}$ Insight software.

Using the ImageJ software with the ObjectJ plugin v.1.03 and its 'Tree Rings' extension (Ferrieria \& Rasband 2019), modified to analyze otolith rings, the total number of daily increments (DI) from the first feeding check (described by Palomera et al. 1988) was counted along the longest axis from the nucleus, and, when the rings were not clearly visible all along this axis, marking was continued along the axis where rings could be clearly identified. Additionally, the individual growth rate (IGR, $\mathrm{mm} \mathrm{d}^{-1}$ ) from the time of hatching until the time of capture was calculated using the equation proposed by Takahashi \& Watanabe (2005) for Japanese anchovy E. japonicus:

$$
\mathrm{IGR}=\frac{\left(\mathrm{TL}-\mathrm{TL}_{0}\right)}{\text { Age }}
$$

where TL is the measured larva total length corrected using the method of Theilacker (1980), $\mathrm{TL}_{0}$ is the standard larva length at hatching, estimated to be $2.5 \mathrm{~mm}$ according to laboratory studies on Cape anchovy (Regner 1985), and Age = DI.

\subsection{Nucleic acid quantification}

Homogenization and quantification of RNA and DNA were carried out at GEOMAR following the methods described in Malzahn et al. (2003). Larval tissue cells were lysed to dissociate proteins using sodium dodecylsulfate (SDS $0.01 \%$ ) in a buffer containing $0.05 \mathrm{M}$ Tris, $0.01 \mathrm{M} \mathrm{EDTA}$, and $0.1 \mathrm{M} \mathrm{NaCl}$ at a $\mathrm{pH}$ of 8.0 (TE buffer). After centrifuging the samples, 2 aliquots of the supernatant were added to a microplate containing the fluorophore Ethidium Bromide (EB). RNase was added to the second aliquot, and the plate was incubated for $30 \mathrm{~min}$ at $37^{\circ} \mathrm{C}$ and then cooled to room temperature before the fluorescence of both aliquots was recorded with a microplate fluorometer. The fluorescence from the RNase-treated aliquot was attributed to DNA. RNA concentrations were calculated from the difference in fluorescence between the 2 aliquots. The RNA:DNA ratios were then standardized (SRD) using the reference slope ratio of 2.4 (Caldarone et al. 2006). In order to eliminate possible bias due to the differences in temperature between the Algoa Bay and west coast sampling stations, the sRD values were incorporated into a multispecies growth model (Buckley et al. 2008) used to calculate larval instantaneous growth rate $\left(G_{\mathrm{i}}\right)$ :

$$
G_{\mathrm{i}}=0.0145 \times \mathrm{sRD}+0.0044 \times(\mathrm{sRD} \times T)-0.078
$$

where $T$ is the average sea temperature in each region as estimated above (i.e. mean surface to $30 \mathrm{~m}$ depth).

\subsection{Statistical analysis}

After testing for normality, independent sample ttests were used to verify differences in the logtransformed environmental parameters (temperature, salinity, oxygen concentration, and chlorophyll a) and the zooplankton biomass between the west coast sites and Algoa Bay. Linear regressions were performed to test the relationships between $\mathrm{TL}$, increment width, against DI, and of sRD and $G_{\mathrm{i}}$ against TL within each area. The significance tests 
for differences in growth (i.e. variables IGR, TL and increment width) and nutritional condition (i.e. variables sRD and $G_{\mathrm{i}}$ ) between west coast and Algoa Bay larval groups were done by applying ANCOVA, using DI and TL as covariates. The biological variables were log-transformed prior to statistical analysis when necessary to obtain linearity and variance homogeneity (Sokal \& Rohlf 1981). Values are presented as mean \pm standard deviation (SD). All statistical analyses were performed using R (CRAN R v3.6.1).

\section{RESULTS}

\subsection{Environmental parameters}

Temperature was significantly lower $(\mathrm{t}=-26.36$, $\mathrm{p}<0.001$ ) in Algoa Bay than at west coast sites $\left(15.61 \pm 2.61\right.$ and $18.28 \pm 3.25^{\circ} \mathrm{C}$, respectively) (Fig. 2). Salinity was also significantly lower $(\mathrm{t}=$ -16.53, p < 0.001) in Algoa Bay than on the west coast (35.08 \pm 0.09 and $38.18 \pm 0.26$ PSU, respectively) (Fig. 2). Oxygen concentration was significantly lower $(\mathrm{t}=-14.92, \mathrm{p}<0.001)$ in Algoa Bay than on the west coast $\left(6.45 \pm 2.60\right.$ and $6.92 \pm 1.51 \mathrm{mg} \mathrm{l}^{-1}$, respectively) (Fig. 2). Chlorophyll concentration in Algoa Bay $\left(3.79 \pm 5.01 \mathrm{mg} \mathrm{l}^{-1}\right)$ was significantly higher $(\mathrm{t}=$ 16.27, $\mathrm{p}<0.001)$ than on the west coast $(1.17 \pm$ $2.48 \mathrm{mg} \mathrm{l}^{-1}$ ) (Fig. 2). Zooplankton biomass in Algoa Bay (38.14 mg DW $\mathrm{m}^{-3}$ ) was significantly higher $(\mathrm{t}=$
43.99, $\mathrm{p}<0.001)$ than on the west coast $(11.68 \pm$ $8.14 \mathrm{mg} \mathrm{DW} \mathrm{m}^{-3}$ ) (Fig. 2).

\subsection{Otolith analyses}

We detected strong evidence of an increase in IGR with TL in both areas ( $p<0.001$; Table 1$)$. However, the relationship between IGR and the number of DI was only positive for larvae from Algoa Bay (Table 1, Fig. 3A). The ANCOVA test indicated that, after controlling for the effect of the DI covariate, there was a significant effect of sampling area on the IGR $\left(F_{1,88}=\right.$ 34.47, p < 0.001), with IGR being higher in the Algoa Bay larvae.

The linear relationship between TL and the number of DI was positive and statistically significant for both Algoa Bay and the west coast ( $\mathrm{p}<0.001$; Table 1, Fig. 3B). The ANCOVA test indicated that, after controlling for the effect of the DI covariate, there was a significant effect of sampling area on the TL $\left(F_{1,88}=48.65, \mathrm{p}<0.001\right)$. For a given age, larvae from Algoa Bay were larger than larvae from the west coast. Therefore, for any given age, IGR was higher in larvae from Algoa Bay than in larvae from the west coast (Table 1, Fig. 3A).

The average increment width increased significantly with DI for fish in Algoa Bay ( $<<0.001)$, while there was no discernable trend for west coast specimens (Table 1, Fig. 3C). The ANCOVA test indicated that, after controlling for the effect of the DI covari-
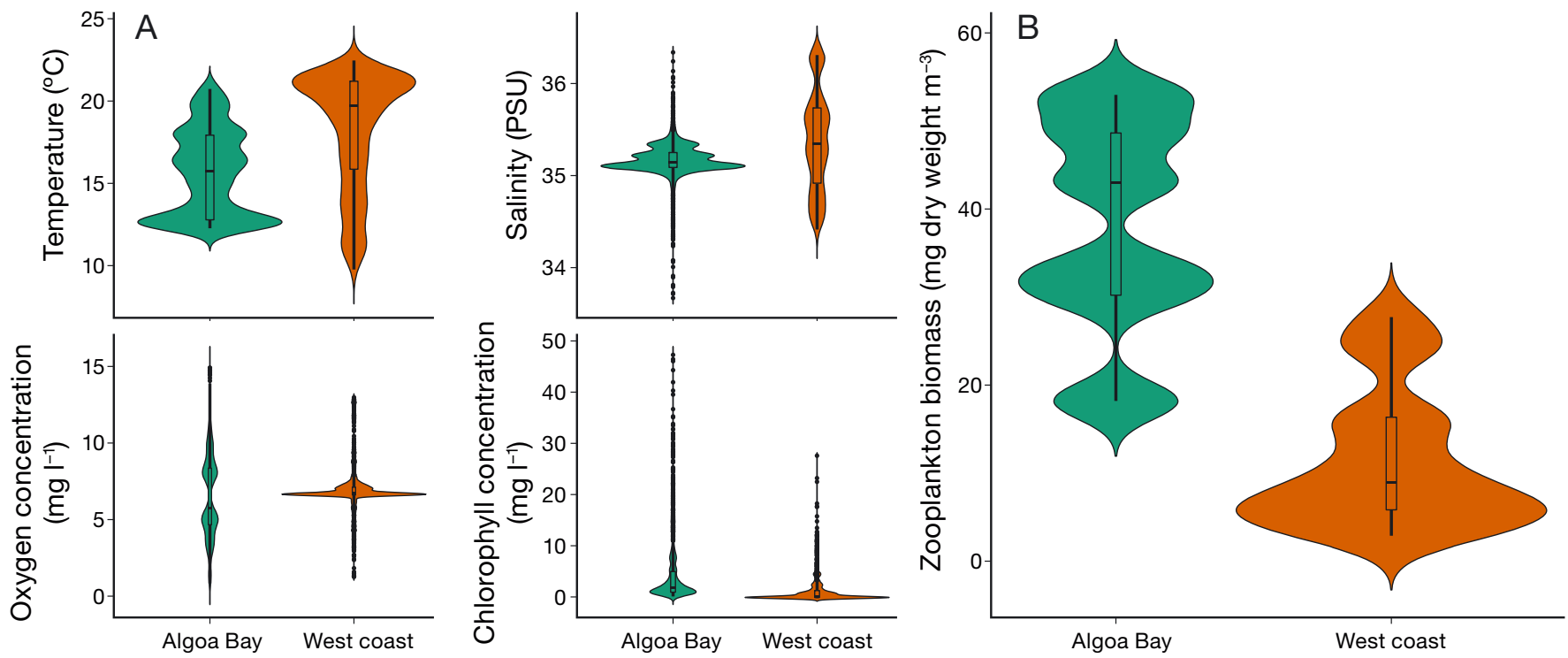

Fig. 2. Plots indicating median (horizontal line), 25-75\% interquartile range (box) and values 1.5 times above/below the interquartiles (vertical lines), and violin plots showing the kernel probability density of the data for (A) sea surface temperature (top left), salinity (top right), oxygen concentration (bottom left) and chlorophyll concentration (bottom right); and

(B) Zooplankton biomass at the time of sampling in Algoa Bay and on the west coast 
Table 1. Estimated coefficients of the linear regressions (dependent variable $[D V]=$ intercept + covariate $\times a$ ). $\mathrm{SE}=\mathrm{standard}$ error, $\mathrm{IGR}=$ individual growth rate, $\mathrm{sRD}=$ standardized RNA:DNA, $G_{\mathrm{i}}=$ instantaneous growth rate, $\mathrm{TL}=$ fish total length, $\mathrm{DI}=$ daily increments. Asterisks indicate significance thresholds: ${ }^{*} \mathrm{p}<0.05,{ }^{* *} \mathrm{p}<0.01,{ }^{* * *} \mathrm{p}<0.001$

\begin{tabular}{|c|c|c|c|c|c|}
\hline DV & Covariate & Intercept $( \pm \mathrm{SE})$ & $a( \pm \mathrm{SE})$ & $\mathrm{r}^{2}$ & $\mathrm{p}$ \\
\hline \multicolumn{6}{|l|}{ Algoa Bay } \\
\hline IGR & TL & $0.17( \pm 0.06)^{* *}$ & $0.03( \pm 0.003)^{* * *}$ & 0.69 & $<0.001^{* * *}$ \\
\hline IGR & DI & $0.25( \pm 0.13)$ & $0.02( \pm 0.008)^{* *}$ & & \\
\hline $\mathrm{TL}$ & DI & $-3.86( \pm 1.88)^{*}$ & $1.10( \pm 0.11)^{* * *}$ & 0.71 & $<0.001^{* * *}$ \\
\hline Increment width & DI & $0.48( \pm 0.53)$ & $0.14( \pm 0.03)^{* * *}$ & 0.32 & $<0.001^{* * *}$ \\
\hline sRD & $\mathrm{TL}$ & $1.52( \pm 1.16)^{* * *}$ & $0.05( \pm 0.02)^{*}$ & 0.12 & $0.013^{*}$ \\
\hline$G_{\mathrm{i}}$ & $\mathrm{TL}$ & $0.05( \pm 0.01)^{* * *}$ & $0.004( \pm 0.001)^{*}$ & 0.12 & $0.013^{*}$ \\
\hline \multicolumn{6}{|l|}{ West coast } \\
\hline IGR & $\mathrm{TL}$ & $0.08( \pm 0.06)$ & $0.04( \pm 0.007)^{* * *}$ & 0.39 & $<0.001^{* * *}$ \\
\hline IGR & DI & $0.53( \pm 0.08)^{* * *}$ & $-0.007( \pm 0.005)$ & & \\
\hline $\mathrm{TL}$ & DI & $3.31( \pm 1.04)^{* *}$ & $0.36( \pm 0.07)^{* * *}$ & 0.34 & $<0.001^{* * *}$ \\
\hline Increment width & DI & $1.72( \pm 0.31)^{* * *}$ & $0.003( \pm 0.02)$ & 0 & 0.86 \\
\hline sRD & TL & $0.86( \pm 0.15)^{* * *}$ & $0.07( \pm 0.01)^{* * *}$ & 0.36 & $<0.001^{* * *}$ \\
\hline$G_{\mathrm{i}}$ & TL & $-0.02( \pm 0.009)^{*}$ & $0.004( \pm 0)^{* * *}$ & 0.35 & $<0.001^{* * *}$ \\
\hline
\end{tabular}
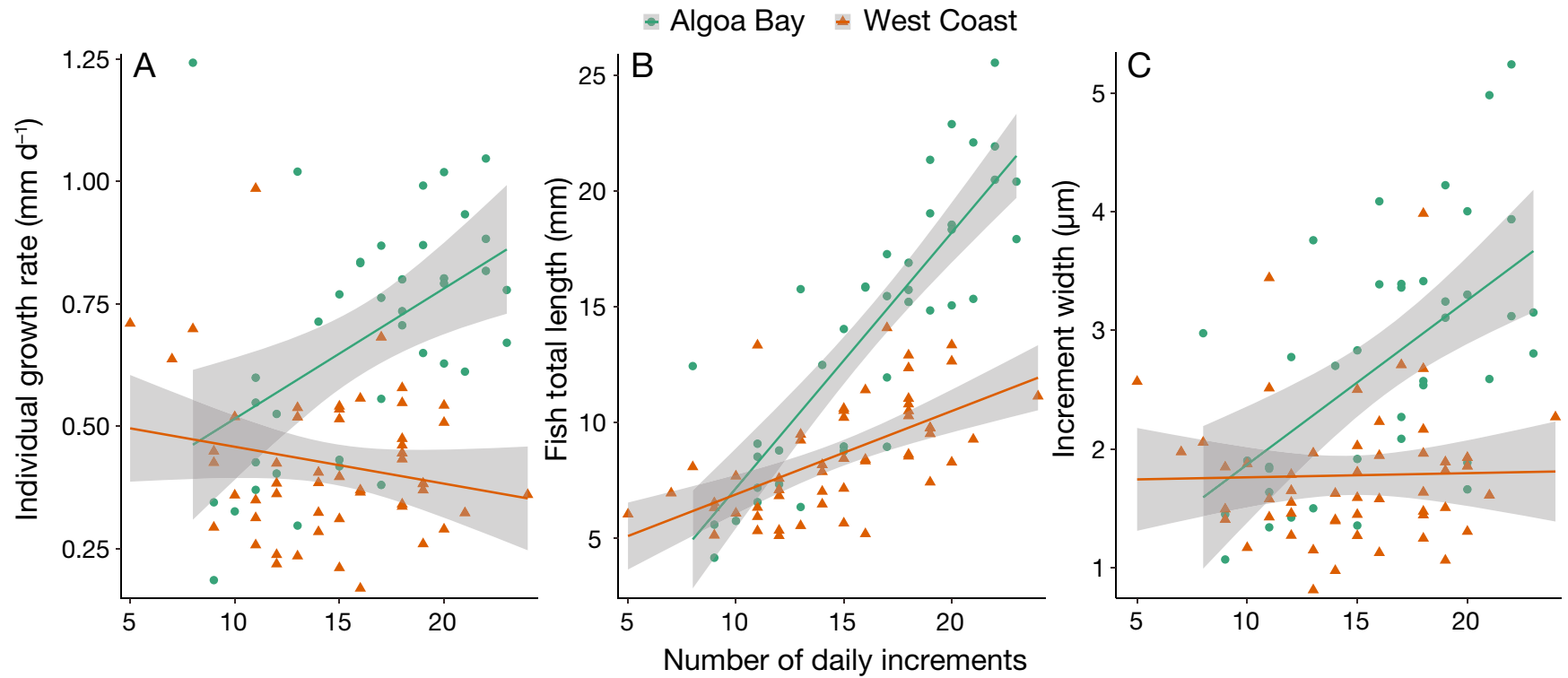

Fig. 3. Relationship between (A) individual growth rates (derived from otolith analyses), (B) total body length, and (C) increment width and the otolith's number of daily increments (i.e. age) of Engraulis encrasicolus larvae sampled in Algoa Bay and on the west coast. Shaded areas indicate $95 \%$ confidence interval for each area

ate, there was a significant effect of the sampling area on the increment width $\left(F_{1,88}=26.64, \mathrm{p}<0.001\right)$.

\subsection{RNA:DNA analysis}

The linear regression indicated a statistically significant increase in SRD with TL in both areas (Table 1, Fig. 4A). The ANCOVA test indicated that, after controlling for the effect of the TL covariate, there was a significant effect of the study area on the $\operatorname{sRD}\left(F_{1,89}=48.15, \mathrm{p}<0.001\right)$, with the slope being steeper for the west coast samples. In addition, the sRD-TL intercept was almost twice as high in the Algoa Bay model than in the west coast model (1.52 and 0.86 , respectively).

The linear regression also indicated a statistically significant increase in $G_{\mathrm{i}}$ with TL in both areas (Table 1, Fig. 4B). The intercept was significantly higher in Algoa Bay than in the west coast, but the slope was steeper for the west coast samples, according to the ANCOVA test $\left(F_{1,89}=138.04, \mathrm{p}<0.001\right)$. Further, at any given larval length, the sRD and the $G_{\mathrm{i}}$ values for Algoa Bay anchovy were much higher 


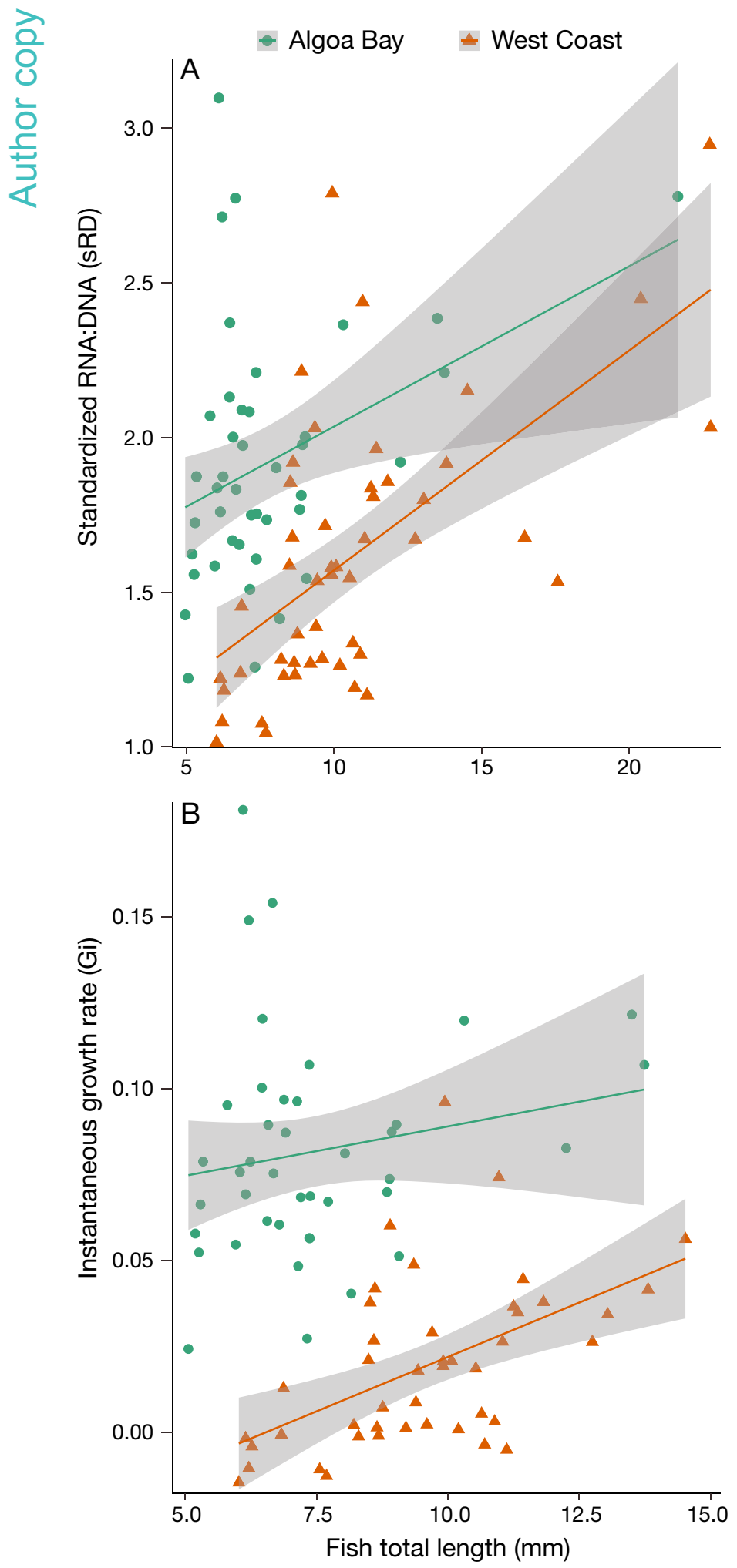

Fig. 4. Relationship between (A) standardized RNA:DNA ratio, and (B) instantaneous growth rate and fish length in the larvae of Engraulis encrasicolus sampled in Algoa Bay and on the west coast. Shaded areas indicate $95 \%$ confidence interval for each area than those of anchovy caught on the west coast ( $\mathrm{p}=$ 0.001 and $\mathrm{p}<0.001$ for sRD and $G_{\mathrm{i}}$, respectively).

\section{DISCUSSION}

The present study aimed to compare the growth and nutritional condition of larval Cape anchovy on the west and southeast coasts of South Africa. Growth rates and nutritional condition of fish larvae were inferred using otolith analyses and RNA:DNA (Clemmesen 1994, Bergeron 2000). The results indicated that in terms of nutritional condition, anchovy larvae might do as well, if not better, in Algoa Bay, situated along the Aghulas Current LME, than in the west coast sampling locations occurring along the comparatively eutrophic Benguela Current LME. This indicates that the environmental conditions in Algoa Bay at the time of sampling may be favorable for the recruitment of anchovy larvae. However, at the time of sampling, average chlorophyll and zooplankton biomass were higher at the Algoa Bay sampling sites than the West Coast sampling sites. Thus, the high productivity in this specific area may have counteracted the potential negative effects of relatively nutrient-poor waters arising from the Aghulas Current. However, these results may only represent a snapshot in time of the potential differences between sample sites on the west coast and Algoa Bay and may not be indicative of the entire Benguela Current or Aghulas Current LMEs. More detailed sampling of larval condition and environmental parameters across spatial and temporal distributions in the 2 areas may provide further clarity. However, the data indicate that the conditions and oceanographic features in Algoa Bay may provide an ideal nursery for viable anchovy recruitment in a southeast coast population.

Stable oceanic conditions allow for aggregations of food which further support larval survival (Lasker 1978, 1981, Santojanni et al. 2006). Algoa Bay is relatively protected from turbulence and is an oceanographically more stable habitat than less sheltered areas (Pattrick et al. 2013), hence providing an adequate nursery area for fish larvae (Lasker 1981, Bergeron 2000). The timing of the availability of food corresponding to the timing of the presence of larvae is integral to determining recruitment success of fish populations (Cushing 1990, García et al. 2003, Takasuka et al. 2007). However, high food availability in certain regions, such as the west coast, may lead to higher interand intra-specific competition which may decrease 
individual body condition in larvae despite higher abundances. For example, Diaz et al. (2018) showed that, for E. anchoita in the southwestern Atlantic Ocean, larvae were in better condition during lowproductivity years than high-productivity years with high densities. Similarly, favorable feeding and environmental conditions also occur seasonally for engraulids, as previously indicated by García et al. (2003), Schismenou et al. (2013) and Do Souto et al. (2019). Somarakis \& Nikolioudakis (2007) found higher densities of $E$. encrasicolus during periods of cooler, freshwater-rich high productivity in the Thermaikos Gulf arising from high riverine discharge. This potential reduction in intra-specific competition in Algoa Bay, combined with favorable conditions for the larvae and their food sources, may explain the similarity in body condition between the sample sites in this study. Given the oceanographic features of Algoa Bay, such as localized upwelling, river discharge and wind-driven retaining countercurrents, it may be an ideal ecosystem for the retention, survival and condition of fish larvae such as anchovy, supporting the hypothesis that the bay is important as a nursery area (Pattrick \& Strydom 2014) by fulfilling the criteria of Bakun's Ocean Triad hypothesis (Bakun 1996, Teodósio et al. 2017).

Alternatively, feeding differences may explain anchovy larvae growth and nutritional condition patterns in oligotrophic areas (Clemmesen 1994, Bergeron 2000). For instance, Quintanilla et al. (2015) showed that the larvae of E. encrasicolus exhibited prey selectivity in low-productivity areas, whereas generalist feeding behavior was seen when food was readily available. Anchovy populations are also known to select larger prey of higher trophic position when it is available in the northwest Mediterranean Sea (Quintanilla et al. 2015, Intxausti et al. 2017). This may also be possible for Algoa Bay and other pelagic fish nurseries along the Aghulas Current LME during periods of low productivity; however, in the present study, zooplankton prey items were not differentiated by type or size so data on differences in feeding preferences between west and southeast coast populations are not available. Also, average chlorophyll and zooplankton densities were higher in Algoa Bay than on the west coast during sampling at this single point in time, which further calls into question potential feeding differences as an explanation for the results of this study over wider spatial-temporal scales with further feeding information such as prey size, but provides a basis for future work as the environment continues to change along the coast.
The results of this study indicate that, although Algoa Bay is situated in a comparatively lowproductivity current system, it provides conditions for anchovy larvae growth and survival comparable to west coast nursery sites. The relatively recent creation of these conditions has resulted in consequences for the biology and life history of the Cape anchovy, such as the eastern shift in recruiting populations or potentially 2 entirely distinct populations (Roy et al. 2007, de Moor \& Butterworth 2015, de Moor et al. 2017 Costalago et al. 2018). A pertinent question that arises is how these populations should be managed from a fisheries and conservation standpoint going forward in a changing world. de Moor \& Butterworth (2015) showed that a 2-stock system may better reflect abundance data for sardines between the west and southeast coasts of South Africa than a single stock system. The same may be true for anchovy, as these species are managed and targeted together in South Africa. Separate stock assessments and total allowable catches for the 2 regions do exist in the most recent procedures, which came into effect in 2018 (de Moor 2018, Coetzee et al. 2019). The environmental data and oceanographic conditions differed between the sampling sites on the west and southeast coasts, which may explain the differences in nutritional condition of larvae. Algoa Bay is more sheltered and retentive, with fewer incidences of upwelling and a higher reliance on freshwater flow, than the nursery sites on the west coast (Schumann et al. 1991, Pattrick \& Strydom 2008, Costalago et al. 2018). Biologically, this may mean different feeding and growth rate strategies as seen by Quintanilla et al. (2015); however, more information is needed to adequately assess the feeding status of the population in Algoa Bay. Also, the nursery sites on the west coast provide significantly more high-productivity areas for anchovy than the potential pockets of appropriate nursery habitat such as Algoa Bay along the south and southeast coast (Hutchings et al. 2009, Kirkman et al. 2016). The physical, biological and socioeconomic differences such as human population density and economic activity between the 2 systems may, however, also warrant an ecosystem-based approach to management (Kirkman et al. 2016, Siple et al. 2019). Ultimately, due to shifts driven by global change, the results of this study highlight the importance of the management of unique nursery areas such as Algoa Bay and thus the separate management of pelagic fish stocks in the 2 distinct LMEs of the south/southeast and western regions of the South African coastline, where different physical and biological factors are at play. 
Acknowledgements. This study was funded by the Department of Environmental Affairs of South Africa (DEA). We also thank SAEON, Department of Agriculture, Forestry and Fisheries of South Africa (DAFF), Marco Worship (DAFF) and the RV 'Algoa' crew, Raggy Charters, Jenny Huggett from DEA, and Christian Hesse from GEOMAR for their contribution and/or support.

\section{LITERATURE CITED}

Augustyn J, Cockroft A, Kerwath S, Lamberth S and others (2018) South Africa. In: Philips BE, Pérez-Ramírez M (eds) Climate change impacts on fisheries and aquaculture: a global analysis, Vol 1. John Wiley \& Sons, Hoboken, NJ, p 479-522

Bakun A (1996) Patterns in the ocean: ocean processes and marine population dynamics. California Sea Grant, in cooperation with Centro de Investigaciones Biologicas del Noroeste, La Paz, Mexico

Bergeron JP (2000) Effect of strong winds on the nutritional condition of anchovy (Engraulis encrasicolus L.) larvae in the Bay of Biscay, Northeast Atlantic, as inferred from an early field application of the DNA/C index. ICES J Mar Sci 57:249-255

Brothers EB, Mathews CP, Lasker R (1976) Daily growth increments in otoliths from larval and adult fishes. Fish Bull 74:1-8

Buckley LJ (1984) RNA-DNA ratio: an index of larval fish growth in the sea. Mar Biol 80:291-298

Buckley LJ, Caldarone EM, Clemmesen C (2008) Multi-species larval fish growth model based on temperature and fluorometrically derived RNA/DNA ratios: results from a meta-analysis. Mar Ecol Prog Ser 371:221-232

Caldarone EM, Clemmesen CM, Berdalet E, Miller TJ and others (2006) Intercalibration of four spectrofluorometric protocols for measuring RNA/DNA ratios in larval and juvenile fish. Limnol Oceanogr Methods 4:153-163

Catalán IA, Berdalet E, Olivar MP, Roldán C (2007) Response of muscle-based biochemical condition indices to shortterm variations in food availability in post-flexion reared sea bass Dicentrarchus labrax (L.) larvae. J Fish Biol 70: 391-405

Checkley D, Alheit J, Oozeki Y, Roy C (2009) Climate change and small pelagic fish. Cambridge University Press, Cambridge

Clemmesen C (1994) The effect of food availability, age or size on the RNA/DNA ratio of individually measured herring larvae: laboratory calibration. Mar Biol 118: 377-382

Coetzee J, de Moor CL, Butterworth DS (2019) A summary of the South African sardine (and anchovy) fishery. MARAM International Stock Assessment Review Workshop, 2-6 December 2019. MARAM/IWS/2019/Sardine/ BG1, MARAM (Marine Resource Assessment and Management Group), University of Cape Town, Rondebosch

Costalago D, Strydom NA, Frost C, Clemmesen C (2015) Preliminary insight into the relationship between environmental factors and the nutritional condition and growth of Gilchristella aestuaria larvae in the upper reaches of South African estuaries. Environ Biol Fishes 98:2367-2378

Costalago D, Potter P, Pattrick P, Strydom NA (2018) Influence of environmental variables on the larval stages of anchovy, Engraulis encrasicolus, and sardine, Sardinops sagax, in Algoa Bay, South Africa. Environ Biol Fishes 101:225-236

* Crawford RJ, Underhill LG, Raubenheimer C, Dyer B, Martin J (1992) Top predators in the Benguela ecosystemimplications of their trophic position. S Afr J Mar Sci 12: 675-687

* Cury P, Bakun A, Crawford RJ, Jarre A, Quinones RA, Shannon LJ, Verheye HM (2000) Small pelagics in upwelling systems: patterns of interaction and structural changes in 'wasp-waist' ecosystems. ICES J Mar Sci 57:603-618

Cushing DH (1990) Plankton production and year-class strength in fish populations: an update of the match/mismatch hypothesis. In: Blaxter JHS, Southward AJ (eds) Advances in marine biology, Vol 26. Academic Press, Cambridge, MA, p 249-293

de Moor CL (2018) The 2018 operational management procedure for the South African sardine and anchovy resources. FISHERIES/2018/DEC/SWG-PEL/37, DAFF Branch Fisheries Document. DAFF, Cape Town

* de Moor CL, Butterworth DS (2015) Assessing the South African sardine resource: two stocks rather than one? Afr J Mar Sci 37:41-51

de Moor CL, Butterworth DS, Van der Lingen CD (2017) The quantitative use of parasite data in multistock modelling of South African sardine (Sardinops sagax). Can J Fish Aquat Sci 74:1895-1903

* Diaz MV, Marrari M, Casa V, Gattás F, Pájaro M, Macchi GJ (2018) Evaluating environmental forcing on nutritional condition of Engraulis anchoita larvae in a productive area of the Southwestern Atlantic Ocean. Prog Oceanogr 168:13-22

* Do Souto M, Brown DR, Leonarduzzi E, Capitanio FL, Diaz MV (2019) Nutritional condition and otolith growth of Engraulis anchoita larvae: the comparison of two life traits indexes. J Mar Syst 193:94-102

F Fairweather T, Van Der Lingen C, Booth A, Drapeau L, Van Der Westhuizen J (2006) Indicators of sustainable fishing for South African sardine Sardinops sagax and anchovy Engraulis encrasicolus. Afr J Mar Sci 28:661-680

Ferrieria T, Rasband W (2019) ImageJ user guide. US National Institutes of Health, Bethesda, MD

Ferron A, Leggett WC (1994) An appraisal of condition measures for marine fish larvae: contribution to the research programs of GIROQ (Groupe Interuniversitaire de Recherches Océanographiques du Québec) and OPEN (Ocean Production Enhancement Network). In: Blaxter JHS, Southward AJ (eds) Advances in marine biology, Vol 30. Academic Press, Cambridge, MA, p 217-303

* García A, Cortés D, Ramírez T, Giráldez A, Carpena Á (2003) Contribution of larval growth rate variability to the recruitment of the Bay of Málaga anchovy (SW Mediterranean) during 2000-2001 spawning seasons. Sci Mar 67: $477-490$

*Hernandez O, Lehodey P, Senina I, Echevin V, Ayón P, Bertrand A, Gaspar P (2014) Modelling anchovy population in the Humboldt upwelling system. Prog Oceanogr 123:105-122

*Hutchings L, Barange M, Bloomer SF, Boyd AJ and others (1998) Multiple factors affecting South African anchovy recruitment in the spawning, transport and nursery areas. S Afr J Mar Sci 19:211-225

*Hutchings L, Beckley LE, Griffiths MH, Roberts MJ, Sundby S, Van der Lingen C (2002) Spawning on the edge: spawning grounds and nursery areas around the southern African coastline. Mar Freshw Res 53:307-318 
Hutchings L, Van der Lingen CD, Shannon LJ, Crawford RJM and others (2009) The Benguela Current: an ecosystem of four components. Prog Oceanogr 83:15-32

* Intxausti L, Villate F, Motos L, Uriarte I, Iriarte A (2017) Diet variability in European anchovy: a comparative analysis between larval populations of the inner Bay of Biscay and the NW Mediterranean. Hydrobiologia 790:49-65

Kirkman S, Blamey L, Lamont T, Field J and others (2016) Spatial characterisation of the Benguela ecosystem for ecosystem-based management. Afr J Mar Sci 38:7-22

Lamont T, García-Reyes M, Bograd SJ, van der Lingen CD, Sydeman WJ (2018) Upwelling indices for comparative ecosystem studies: variability in the Benguela Upwelling System. J Mar Syst 188:3-16

Lasker R (1978) The relation between oceanographic conditions and larval anchovy food in the California Current: identification of factors contributing to recruitment failure. Rapp P-V Reun Cons Int Explor Mer 173:212-230

Lasker R (1981) The role of a stable ocean in larval fish survival and subsequent recruitment. In: Lasker R (ed) Marine fish larvae: morphology, ecology and relation to fisheries. University of Washington Press, Seattle, WA, p 81-87

Malzahn A, Clemmesen C, Rosenthal H (2003) Temperature effects on growth and nucleic acids in laboratory-reared larval coregonid fish. Mar Ecol Prog Ser 259:285-293

* Molony BW, Choat JH (1990) Otolith increment widths and somatic growth rate: the presence of a time-lag. J Fish Biol 37:541-551

Palomera I, Morales-Nin B, Lleonart J (1988) Larval growth of anchovy, Engraulis encrasicolus, in the Western Mediterranean Sea. Mar Biol 99:283-291

Pattrick P, Strydom NA (2008) Composition, abundance, distribution and seasonality of larval fishes in the shallow nearshore of the proposed Greater Addo Marine Reserve, Algoa Bay, South Africa. Estuar Coast Shelf Sci 79: 251-262

Pattrick P, Strydom NA (2014) Larval fish variability in response to oceanographic features in a nearshore nursery area. J Fish Biol 85:857-881

Pattrick P, Strydom NA, Goschen WS (2013) Shallow-water, nearshore current dynamics in Algoa Bay, South Africa, with notes on the implications for larval fish dispersal. Afr J Mar Sci 35:269-282

* Pichegru L, Ryan PG, Le Bohec C, van der Lingen CD and others (2009) Overlap between vulnerable top predators and fisheries in the Benguela upwelling system: implications for marine protected areas. Mar Ecol Prog Ser 391: 199-208

Quintanilla JM, Laiz-Carrión R, Uriarte A, García A (2015) Influence of trophic pathways on daily growth patterns of western Mediterranean anchovy Engraulis encrasicolus larvae. Mar Ecol Prog Ser 531:263-275

Editorial responsibility: Stylianos Somarakis, Heraklion, Greece
Regner S (1985) Ecology of planktonic stages of the anchovy, Engraulis encrasicolus (Linnaeus, 1758), in the central Adriatic. Acta Adriatica 26(1)

* Roy C, Van der Lingen CD, Coetzee JC, Lutjeharms JRE (2007) Abrupt environmental shift associated with changes in the distribution of Cape anchovy Engraulis encrasicolus spawners in the southern Benguela. Afr J Mar Sci 29:309-319

* Santojanni A, Arneri E, Bernardini V, Cingolani N, Di Marco M, Russo A (2006) Effects of environmental variables on recruitment of anchovy in the Adriatic Sea. Clim Res 31: 181-193

Schismenou E, Tsiaras K, Kourepini MI, Lefkaditou E, Triantafyllou G, Somarakis S (2013) Seasonal changes in growth and condition of anchovy late larvae explained with a hydrodynamic-biogeochemical model simulation. Mar Ecol Prog Ser 478:197-209

Schumann EH, Illenberger WK, Goschen WS (1991) Surface winds over Algoa Bay, South Africa. S Afr J Sci 87:202-207

Siple MC, Essington TE, Plagányi É (2019) Forage fish fisheries management requires a tailored approach to balance trade-offs. Fish Fish 20:110-124

Sokal R, Rohlf F (1981) Biometry, $2^{\text {nd }}$ edn. WH Freeman, San Francisco, CA

* Somarakis S, Nikolioudakis N (2007) Oceanographic habitat, growth and mortality of larval anchovy (Engraulis encrasicolus) in the northern Aegean Sea (eastern Mediterranean). Mar Biol 152:1143-1158

Takahashi M, Watanabe Y (2005) Effects of temperature and food availability on growth rate during late larval stage of Japanese anchovy (Engraulis japonicus) in the KuroshioOyashio transition region. Fish Oceanogr 14:223-235

Takasuka A, Aoki I, Oozeki Y (2007) Predator-specific growth-selective predation on larval Japanese anchovy Engraulis japonicus. Mar Ecol Prog Ser 350:99-107

Teodósio MA, Garrido S, Peters J, Leitão F, Ré P, Peliz A, Santos AMP (2017) Assessing the impact of environmental forcing on the condition of anchovy larvae in the Cadiz Gulf using nucleic acid and fatty acid-derived indices. Estuar Coast Shelf Sci 185:94-106

Theilacker GH (1980) Changes in body measurements of larval northern anchovy, Engraulis mordax, and other fishes due to handling and preservation. Fish Bull 78:685-692

Twatwa NM, Van Der Lingen CD, Drapeau L, Moloney CL, Field JG (2005) Characterising and comparing the spawning habitats of anchovy Engraulis encrasicolus and sardine Sardinops sagax in the southern Benguela upwelling ecosystem. Afr J Mar Sci 27:487-499

*Van der Lingen CD, Hutchings L, Field JG (2006) Comparative trophodynamics of anchovy Engraulis encrasicolus and sardine Sardinops sagax in the southern Benguela: are species alternations between small pelagic fish trophodynamically mediated? Afr J Mar Sci 28:465-477

Submitted: November 5, 2019; Accepted: April 21, 2020

Proofs received from author(s): June 7, 2020 